\title{
Men's Rights and Feminist Advocacy in Canadian Domestic Violence Policy Arenas
}

\section{Contexts, Dynamics, and Outcomes of Antifeminist Backlash}

\author{
Ruth M. Mann \\ University of Windsor
}

\begin{abstract}
This article examines government and advocacy group texts on three recent Canadian domestic violence policy moments. Drawing on governance, feminist poststructuralist, and social movement perspectives, it examines men's rights advocates' and feminists' discursive actions and their influence on officials. The research aim is to explore the provisional, intrinsically incomplete, and indeed questionable success, to date, of Canadian anti-domestic violence advocates' strategies and tactics of resisting men's advocates' efforts to delegitimize gendered constructions of domestic violence. At the level of political action, the article contributes to efforts by feminists internationally to safeguard protections and supports for abused women and children in a political context marked by the increasingly prominent influence of men's rights and associated antiprogressive backlash.
\end{abstract}

Keywords: feminist; feminism; backlash; Canada; violence against women; men's rights; international domestic violence; domestic violence; governance; subjectivities; social movements

$\mathrm{T}$ he overtly angry antifeminist backlash voice of men's or fathers' rights has become an increasingly vocal, visible, and organized presence in public discourse on domestic violence and family law across Western jurisdictions (Bala,1999; Berns, 2004; Boyd, 2003; Boyd \& Young, 2002; Chesney-Lind, 2006; DeKeseredy, 1999, 2006; Jaffe \& Crooks, 2004; Kimmel, 2002; Laing, 1999; Mandell, 2002; Mann, 2005, 2007; Messner, 1998; Minaker \& Snider, 2006; Rhoades \& Boyd, 2006; Schwartz, 2005). In legislative hearings and across a host of print-media and Internet forums, men's advocates and a "cadre" (Miller \& Meloy, 2006, p. 90) of scholars contend that feminism promotes a false gender-specific portrait of domestic violence (e.g., Lupri, 2004; Straus, 1993, 2006). They argue that women are equally or indeed more violent in domestic contexts than men, and that abused

Author's Note: The research for this article was supported by a grant from the Health Research Centre on Violence Against Women, University of Windsor. 
women shelters, restraining orders, antistalking laws, risk assessment tools, and other feminist-supported anti-domestic violence interventions promote hatred of and bias against men. In Canada, these claims coincide with demands that the government stop funding Status of Women Canada, the quasi-governmental agency established in the early 1970s to monitor and promote the advancement of women at federal, provincial-territorial, and international levels (Dobrowolsky \& Jenson, 2004; Morrow, Hankivsky, \& Varcoe, 2004; Shaw \& Andrew, 2005; Walker, 1990; Weldon, 2002).

This article examines efforts by men's advocates to advance this backlash perspective in Canadian domestic violence policy forums in the first few years of the 21 st century. My research aim is to document and critically examine the provisional, intrinsically incomplete (Hunt \& Wickham, 1994), and indeed questionable (Minaker \& Snider, 2006) success, to date, of Canadian feminists' strategies and tactics of resisting men's advocates' efforts to degender domestic violence policy. At the level of political action, I aim to contribute to efforts by feminists internationally to safeguard protections and supports for abused women and children in a political context marked by the increasingly prominent influence of men's rights and associated antiprogressive backlash.

In the following sections of this article, I outline my methodological and theoretical approaches. Building on this, I briefly outline key features of Canada's prevailing "citizenship regime" (Dobrowolsky \& Jenson, 2004, p. 155) and "gender order" (Eisenstein, 1996, 207), focusing on the role Status of Women Canada has played in shaping the institutional arrangements, rules, and working understandings on problem definition and claims making that underpin policy processes in Canada. I then narrate men's advocates' and feminists' interactions with each other and officials in three recent domestic violence policy moments, treating these as protest events for men's rights advocacy, that is, as instances of what Sidney Tarrow $(1996,1998)$ and other social movements scholars name contentious politics (e.g., Aminzade \& McAdam, 2002; Ayres, 1999; Davenport \& Ball, 2002; Earl, Martin, McCarthy, \& Soule, 2004).

The first is a set of hearings in Ontario on a never-to-be-enacted Domestic Violence Protection Act (Bill 117) (Legislative Assembly of Ontario, 2000a, 2000b, 2000c), held in 2000 in the wake of a spate of femicide-suicides and familicides in Ontario. The second is an inquest into one of the femicide-suicides cited at the Bill 117 hearings, the Hadley Coroner Inquest (Domestic Violence Death Review Committee, 2003). The third is a consultation and roundtable on family violence and bullying held in Alberta in 2004, likewise convened in response to a series of familyrelated homicides and suicides (Government of Alberta, 2004a, 2004b, 2004c, 2004d). I conclude with a discussion on the interplay of contextual and dynamic factors in policy outcomes as viewed through governmental and advocacy group discourses on these three policy moments. 


\section{Method and Theory}

The data for this study were collected through a research strategy that is broadly consistent with the approach Tarrow (1996) identifies as "contentious event analysis" (p. 875). Building on the work of Charles Tilly (as cited in Tarrow, 1996), a number of social movement scholars utilize newspaper reports and other textual sources to map protest actions across time and place and to document the discursive repertoires that protestors and officials draw upon and reproduce. This is to say, rather than actively participate in or observe protest events, or pursue advocacy group and governmental representatives to obtain their perspectives, these scholars utilize publicly available texts on contending actors' and officials' actions and interactions. Researchers typically compile and code variously sampled news media accounts of a protest event or set of events, systematically tracking and quantifying media attention and governmental reaction (e.g., Koopmans \& Olzak, 2004). Many triangulate news reports with police records and other governmental and nongovernmental texts or text sources, including advocacy group Web sites (Almeida \& Lichbach, 2003; Mann, 2005). Some additionally employ observational (Schweingruber \& McPhail, 1999), survey (Earl et al., 2004), and/or interview (Blee, 2007; Davenport \& Ball, 2002; Ferree, 2003) methodologies.

Textually based research has the advantage of being a low-cost and, as important, safe strategy for compiling a corpus of data on the activities of individuals and groups who may be difficult to access, suspicious of or hostile to research, or even dangerous to directly observe or interview (Blee, 2007; Davenport \& Ball, 2002). Social movement scholars agree, however, that a triangulation of sources and/or methods is needed to comprehensively tap the ideological commitments of member groups; nuances and contractions on goals, strategies, and tactics within and between member groups; and perhaps most important, the internal dynamics and "emotion cultures" (Aminzade e \& McAdam, 2002, p. 108) that shape action and its impacts within specific "discursive opportunity structures" (Ferree, 2003, p. 308) or contexts (Koopmans \& Olzak, 2004; see also Barnes, Newman, \& Sullivan, 2004; Dilorio \& Nusbaumer, 1993; Earl et al., 2004; Koopmans \& Olzak, 2004; Mann, 2002, 2005; Rohlinger, 2002; Swidler, 1995; Tarrow, 1998; Taylor \& Whittier, 1995). In sum, multiple methods are clearly best, but commentators agree that when limitations are recognized and multiple sources are employed, textually based research can afford valuable insights into the nature and dynamics of contentious politics across time and space, the historically constituted contexts that give rise to contention, and factors that shape policy, protest group, and social movement outcomes.

A final note on textually based research: This is an increasingly appropriate strategy for mapping protest activity and its policy impacts due to the prominence of the Internet as a site of governmental and social movement action, the power of search engines such as Google to access policy- and protest-relevant texts in mainstream and alternative media, and the power of personal computers to store, organize, code, 
and retrieve the vast corpus of discursive data that emerges through an Internet search (Mautner, 2005). Currently, the Internet is far more than a site on which textual data are archived. It is a site of action used by governmental and advocacy groups alike to attract supporters, mobilize participation, and launch actions (Almeida \& Lichbach, 2003; Ayres, 1999; Blee, 2007; Bouchard, Boily, \& Proulx, 2003; Koopmans \& Olzak, 2004; Mann, 2005; Tarrow, 1996, 1998). For researchers, the Internet is therefore both a point of access to records or commentary on action, and a point of access to a form of action itself.

Building on the emergent body of research that exploits the Internet and other textual sources on social action, this article advances a theoretically anchored qualitative analysis of the three domestic violence discourse moments outlined above. As is made clear in my discussion of theory below, my aim is not to test or generate hypothesis on causal processes. Rather, I aim to identify or "diagnose" (Rose, 1999, 21), in the Foucauldian tradition, the dynamics of contestation and its policy impacts (see also Cooper, 1994; Hunt, 1997, 1999; Hunt \& Wickham, 1994; Rose \& Valverde, 1998; Swidler, 1995; Weedon, 1987; Wodak, 2006).

I rely on two Internet-accessed data sources. The first is Web sites of the governments of Canada, Ontario, and Alberta, each of which post online reports and commentary on domestic violence policy and, more important, official Hansard transcripts of committee hearings and legislative debates of proceedings on these policies. These verbatim transcripts, named after Thomas Hansard, the publisher of the report of debates at the U.K. Parliament in the early 19th century (Hansard Association of Canada, 2007), capture the extensive and often highly emotional phase of deliberation and debate that informs lawmaking in Canada, during which testimony from interested individuals and groups is taken. The Hansards, as they are reflexively referred to by parliamentarians and journalists, are consequently a singularly valuable data source on legislative processes. They capture all not-in-camera proceedings of federal and provincial legislatures, and include the names, self-identified affiliations, and testimony of all citizens who come before legislative committees. A researcher can therefore map the discursive actions of individual activists, activist groups, and politicians across policy moments, comparing, for example, arguments that competing actors advanced in federal divorce law reform deliberations in the closing years of the 20th century with those subsequently advanced in provincial domestic violence hearings, as will be the case in this article.

The second data source is advocacy group Web sites that participated in and/or provide engaged commentary on one or more of the three domestic violence policy moments, several of which post news media reports on these actions. All were selected because they are named in the Hansards, or because they appeared as a "hit" in a 10-page Google search on the three domestic violence policy moments, conducted in 2005 and 2006. Seven men's rights Web sites qualify: B.C. Fathers, Equal Parents of Canada, Family of Men, Fathers Are Capable Too, Fathers Canada 4 Justice, Fathers for Life, and the Men's Educational Support Association. All seven 
adopt a "masculinist" (Bouchard et al., 2003) stance on domestic violence, marked by assertions that women are equally or more violent against intimate partners and children than are men. All, moreover, engage in more or less "rabid" (DeKeseredy, 2006, p. 1079) attacks on feminism, on their Web sites, and/or in Hansard-captured testimony. Feminist actions and commentary come from nine feminist or womancentered Web sites of groups that participated in or comment on one or more of the three policy moments: Alberta Women's Issues, Alberta's Action Committee Against Violence, Alberta's Research and Education for Solutions to Violence and Abuse, Alberta's Sexual Assault Centre of Edmonton, the National Council of Women of Canada, the Ontario Association of Interval and Transition Houses, the Ontario Women's Directorate, the Ontario Women's Justice Network , and Status of Women Canada. All nine frame domestic violence and homicide as predominantly but not exclusively male perpetrated. It is important to note that all refrain from reciprocating men's rights "vitriol" (Mann, 2005, p. 37), both on their Web sites and in Hansard-captured testimony.

Responding to calls for a more interdisciplinary theoretical approach to discourse analysis (Wodak, 2006, p. 186), my reading of the data draws on three theoretical perspectives on distinct but interrelated processes relevant to backlash and the politics of domestic violence. First, I draw on a governance perspective to situate the policy moments and participants' actions in relation to "advanced liberal" (Rose, 1999, p. 140) efforts by federal and provincial governments to stimulate self-governance of interpersonal conduct and broad-based participation and "partnering" in stateorchestrated efforts to identify, prevent, and solve social/moral problems through criminal justice and community-based interventions (see also Hunt, 1997, 1999; Hunt \& Wickham, 1994; Rose \& Valverde, 1998). This analytic focus is particularly appropriate in the case of Canada, where the development and reform of law and policy proceed through formal efforts to incorporate the perspectives of all citizens, while giving "voice," in particular, "to the situations and concerns of citizens who find themselves on the margins" (Department of Justice Canada, 2005; see also Dobrowolsky \& Jenson, 2004).

Second, I draw on feminist poststructural understandings of the interpenetration of discourse, subjectivity, and culture, and their relevance to power, gender, violence, citizenship, governance, and resistance at interpersonal, and by implication, collective levels. This approach compels researchers to attend to the diversity and multiplicity of gendered experiences of women and men (Boonzaier \& De La Rey, 2003; Burgess-Proctor, 2006; Cooper, 1994; Taylor \& Whittier, 1995; Towns \& Adams, 2000; Weedon, 1987; Wodak, 2006). Viewing this diversity as an effect of the socialcultural-institutional matrix within which human subjects are located, it looks to the specifics of interactional and social contexts to explore how gender and other power relations are produced and deployed. In the context of domestic violence, it compels researchers to attend to the ambiguities and contradictions of meanings, motives, and impacts on victimized, defending, and offending women and men, including the 
ways varying patterns produce, or fail to produce, fear and control (Anderson, 2005; Anderson \& Umberson, 2001; Cook \& Goodman, 2006; Dasgupta, 2002; Dobash \& Dobash, 2004; Dobash, Dobash, Cavanagh, \& Lewis, 1998; Hamberger \& Guse, 2002; Johnson, 1995, 2006; Mann, 2000; 2007; McMahon \& Pence, 2003; Miller, 2006; Miller \& Meloy, 2006; Schwartz, 2005; Swan \& Snow, 2006; Tutty, 1999). At the same time, it compels researchers to attend to how gendered practices interact with class, race, and other statuses and practices to produce a constellation around which domestic violence and other criminal acts occur, can be understood, and are punished, including how abuse in childhood contributes to violence and victimization (Burgess-Proctor, 2006; Dobash \& Dobash, 2004; Dobash et al., 1998; Mann, 2000; Potter, 2006; Schwartz, 2005; Snider, 1998; Worcester, 2002). Finally, it contributes to understandings of the "political subjectivity" (Hunt, 1997, p. 282; see also Hunt, 1999; Rose \& Valverde, 1998) and self-formation of feminism and other collective agents who endeavor to shape policy and other social outcomes.

Last, my analysis draws on social movement scholarship on the ways social movements' discourses and identities shape movement-countermovement dynamics and strategies and, ultimately, policy outcomes (Aminzade \& McAdam, 2002; Einwohner, 2002; Mann, 2002; McCaffrey \& Keys, 2000; Rohlinger, 2002; Swidler, 1995; Tarrow, 1998; Taylor \& Rupp, 2002; Taylor \& Whittier, 1995; Whittier, 2001). This perspective recognizes that a movement's discourse, collectively forged, constitutes, reproduces, and celebrates the "who we are" (Polletta \& Jasper, 2001, p. 292) of movement advocates, and that it is to a movement's discursive displays that audiences respond. It attends, therefore, to how discursive repertoires are strategically produced and deployed in a movement's self-formation and self-projection, including the ways "reverse discourses" (Cooper, 1994; Weedon, 1987), ${ }^{1}$ emotion management (Dilorio \& Nusbaumer, 1993), and other resistance tactics interact with other forms of power and social-political conditions to advance or hinder collective goals. This analytic approach renders intelligible men's advocates' deployment of discourses of inequality, disempowerment, sexist stereotyping, and silencing to "frame" (Berns, 2004) feminism as causing men to be persecuted, mocked, and denigrated, and as seeking to take away men's human and civil rights (Kimmel, 2002; Messner, 1998). It also renders intelligible feminism's self-monitoring of its anger and its use of discourses and practices of theoretically sound, methodologically rigorous, and contextually anchored research to situate feminism and its domestic violence project as defendable and trustworthy (Dasgupta, 2002; DeKeseredy, 2006; Dobash \& Dobash, 1995, 1998, 2004; Dobash et al., 1998; Hamberger \& Guse, 2002; Johnson, 1995, 2006; Mann, 2005; Miller, 2006; Miller \& Meloy, 2006; Rhoades \& Boyd, 2006; Schwartz, 2005; Swan \& Snow, 2006; Tutty, 1999; Worcester, 2002).

As Hunt $(1997,1999)$ emphasizes, and as numerous other scholars note, contestation over gender is marked by intense anger and, just as important, by a rhetoric of anger that is especially strident in discourse on domestic violence (Bertoia \& 
Drakich, 1993; Boyd \& Young, 2002; Breines \& Gordon, 1983; Crean, 1988; DeKeseredy, 1999, 2006; Gelles \& Loseke, 1993; Kimmel, 2002; Mann, 2000, 2002, 2005, 2007; Messner, 1998). Recognizing the collective and strategic nature of this development, this article now turns to the governance of gender, focusing on the role Status of Women Canada has played in shaping the institutional arrangements, rules, and working understandings on problem definition and claims making that underpin domestic violence policies and men's advocates' challenges to these policies in the Canadian context.

\section{The New Gender Order and Canada's Prevailing Citizenship Regime}

Across contemporary Western societies, women and men are enjoined by a host of state and nonstate entities to govern their own and each others' intimate conduct. This ideally occurs through mutual voluntary acceptance and "willed subordination" (Rose, 1999, p. 187) to a new democratization of intimacy and the norms of civility, flexibility, cooperation and openness that underpin this post-patriarchal family order (Cherlin, 2004; Hunt, 1999). This order mandates enhanced autonomy or freedom for individuals to enter into and exit intimate relationships but also intensified responsibility to fulfill obligations undertaken through intimacy. In Canada, as in most Western jurisdictions, individuals are free to enter into and exit a legal marriage or common-law union without excuse or penalty, which is to say without fault (LeBourdais \& Lapierre-Adamcyk, 2004). They are also free, in the event of relationship breakdown, to negotiate the details of how they will divide property and meet parenting responsibilities (Juby, LeBourdais, \& Marcil-Gratton, 2005). Individuals are not free, however, to financially abandon a child or children. Nor are they free to resort to coercion, intimidation, bullying, or violence. Once abandonment or violence occurs, the enabling activating state becomes the intrusive sovereign state, mandated to investigate and penalize as "anti-citizens" (Rose, 1999, p, 88) those who refuse, or fail to meet, their responsibilities as parents and partners.

The primary technology of rule supporting this new citizenship regime (Dobrowolsky \& Jenson, 2004) is ethical subjectification (Hunt, 1997, 1999; Rose, 1999; Rose \& Valverde, 1998). As Hunt (1997) and other governance scholars frame this, we are made up, and we are enjoined to make up ourselves, as citizens who will freely and fairly play the "community-civility game" (Rose, 1999, p. 188), not just in private contexts but, as important, in public interactions, including especially interactions with officials (Barnes et al., 2004). Authoritarian exclusions are reserved for those who refuse or who appear unable or unwilling to accept this subjectification-on whom radical, batterer, deadbeat, and other negative identities are imposed.

Status of Women Canada (hereafter Status of Women) was founded in 1973 in the wake of the 1967 Royal Commission on the Status of Women. Operating at federal 
and provincial-territorial levels in cooperation with women's directorates and ministries, it brings together paid and volunteer researchers and service providers across a range of women's organizations with the official mandate to monitor and promote the social, economic, and political advancement of women (Dobrowolsky \& Jenson, 2004; Morrow et al., 2004; Shaw \& Andrew, 2005; Walker, 1990; Weldon, 2002). Although it is not officially feminist, this "women's policy machinery" (Eisenstein 1996, p. 43) is a key site through which a broad range of feminist and feministsympathetic individuals and groups network and strategize to enhance supports for women in need, conduct research, inform the public, and pressure government on women's issues. Situated within a larger governmental project that purports to incorporate and respond to the concerns of all citizens (Department of Justice Canada, 2005), Status of Women is responsible for a number of policy successes that are relevant to anti-domestic violence efforts and backlash in Canada.

Most important, in cooperation with other progressive and women-oriented agencies and groups, Status of Women succeeded in convincing the Government of Canada to include gender and other markers of inequality (race, color, religion, disability) as criteria against which discrimination is expressly prohibited in Section 15(1) of the 1982 Canadian Charter of Rights and Freedoms (MacKinnon, 2006; Shaw \& Andrew, 2005; Weldon, 2002). As important, it convinced the government to authorize laws, programs, and activities aimed at "the amelioration of conditions of disadvantaged individuals or groups" (Sec. 15(2)). Moreover, it succeeded in convincing the government to include a special provision (Sec. 28) that explicitly states that all provisions of the charter apply equally to "male and female persons," making the Canadian Charter of Rights and Freedoms "advanced beyond any comparable instrument in the world today in promising full citizenship to women" (MacKinnon, 2006, p. 79).

Building on this foundation, again in cooperation with other progressive and women-oriented groups, Status of Women succeeded in locating violence against women and children as a key focus within the 1988 federal Family Violence Initiative (FVI) (Morrow et al., 2004; Shaw \& Andrew, 2005; Walker, 1990; Weldon, 2002). This broad-based multiagency coordinating and funding initiative aims to prevent all forms of intimate violence through multilevel partnerships that link federal and provincial-territorial agencies with a broad range of civil society groups (Public Health Agency of Canada, 2006). ${ }^{2}$ As one of seven funded FVI partners, Status of Women has helped conduct and disseminate research and information on the impacts of domestic violence on women and children, including what Peter Jaffe and Claire Crooks (2004, p. 917) refer to as a burgeoning literature on the impacts on children of witnessing domestic violence. It has also helped develop and refine domestic violence intervention training manuals, safety audits, and other intervention tools; question and rethink justice policies that disproportionally penalize marginalized constituencies, including especially Aboriginal and immigrant women; and build and support Canada's extensive network of women's shelters and associated 
victim services. Finally, with increasing urgency, Status of Women has helped develop primary perpetrator policies to counter the trend in dual arrests that men's advocates herald as proof that women are equally violent (McMahon \& Pence, 2003), a trend that a growing body of Canadian and international research indicates largely criminalize abused women who are fighting back against male violence and control (see also Chesney-Lind, 2006; Dasgupta, 2002; Hamberger \& Guse, 2002; Mann, 2007; Miller, 2006; Miller \& Meloy, 2006; Minaker \& Snider, 2006; Tutty, 1999).

Cognizant of the experiential and political complexities of domestic violence and the challenges and contradictions of effective intervention, Status of Women carefully frames the domestic violence problem as simultaneously gender-neutral and gender-specific, a framing that Statistics Canada and other FVI partners also substantively endorse (e.g., AuCoin, 2005; Ogrodnik, 2006; Public Health Agency of Canada, 2006):

Violence against anyone is unacceptable whether it is directed against children, women, men, seniors, people with disabilities, visible minorities or anyone else.

Violence against anyone is unacceptable. Violence experienced by women, however, particularly intimate partner violence and sexual assault, represents a unique aspect of the wider social problem of violence and requires specific attention and solutions. Individual experiences of violence against women must be assessed against the backdrop of historical, social, political, cultural, and economic inequality of women. (Federal-Provincial-Territorial Ministries, 2002, opening statement)

Status of Women's framing of the domestic violence problem in the above excerpts is an example of the type of discursive compromise that marks Status of Women's rhetoric on domestic violence at the present moment. Effectively, Status of Women locates its implicit feminist bias within prevailing "discourse opportunity structures" (Ferree, 2003, p. 308) that call for equal concern for and treatment of all victims, without, however, sacrificing the key feminist position that violence against women is rooted in and reproduces women's inequality. As the following section of this article emphasizes, men's advocates miss or ignore this nuance, insisting that Status of Women, and feminism, are radically and dangerously antimale.

\section{Men's Rights Backlash and Family Violence Research}

From the 1982 charter victory forward, Status of Women and the programs and policies it supports have elicited backlash. From the 1980s (Bertoia \& Drakich, 1993; Boyd \& Young, 2002; Crean, 1988) through the recent present (Bala, 1999; Boyd, 2003; DeKeseredy, 1999, 2006; Jaffe \& Crooks, 2004; Laing, 1999; Mann, 2005, 2007; Minaker \& Snider, 2006; Rhoades \& Boyd, 2006), men's advocates have denounced Status of Women and other FVI partners for intentionally hiding and distorting evidence on female perpetration, for falsely framing domestic violence as a gender rather than a human problem, for fostering "moral panic" (Fekete, 
1994; see also Lupri, 2004) by exaggerating the scope and impact of violence against women and children, and for encouraging false allegations of spousal violence and child abuse in child custody hearings (on men's rights activism at the intersection of domestic violence and family law outside Canada, see Jaffe \& Crooks, 2004; Messner, 1998; Rhoades \& Boyd, 2006).

These efforts draw on findings of gender symmetry in domestic violence in research conducted by Murray Straus and others associated with or building on the work of the New Hampshire Family Violence Laboratory (see Fiebert's 2006 internet-disseminated listing of research on gender symmetry). As reiterated in reviews of contending perspectives across the family violence and feminist divide from the early 1980 s forward, differences initially centered on the relative validity of quantitative act-based versus qualitative narrative-based measures (Anderson, 2005; Breines \& Gordon, 1983; Gelles \& Loseke, 1993; Johnson, 1995, 2006; Kimmel, 2002; Straus, 1993, 2006; Tutty, 1999). Family violence advocates argue, however, that the research instrument that is at the foundation of their research, the Conflict Tactics Scale, proves the need for a broader understanding and intervention response than the ideologically rooted gender-specific analysis offered by feminists.

On the other side, feminists have insisted that the Conflict Tactics Scale neither addresses nor captures the reality of battering, a reality evidenced in the testimony and tortured and murdered bodies of battered women. Over the past decade, however, feminists have rethought (Dobash \& Dobash, 1998) how to best build theoretically sound and empirically verifiable understandings on the "puzzle" (Dobash \& Dobash, 2004, 324) of women's as well as men's use of violent tactics in intimate relationships. Currently, many feminist or gender-sensitive researchers participate in an effort that utilizes various versions of the Conflict Tactics Scale in conjunction with a growing repertoire of qualitative and quantitative measures of the dynamics and consequences of battering, FVI partner Statistics Canada among them (AuCoin 2005; Ogrodnik, 2006; see critique in Minaker \& Snider, 2006). The aim is to type and map various domestic violence patterns and how gendered experiences and selfunderstandings shape the dynamics and differential meanings and consequences of violence for men, women, and children (Anderson, 2005; Anderson \& Umberson, 2001; Boonzaier \& La Rey, 2003; Cook \& Goodman, 2006; Dasgupta, 2002; DeKeseredy, 2006; Dobash et al., 1998; Hamberger \& Guse, 2002; Johnson, 1995, 2006; Mann, 2000, 2002, 2007; Miller, 2006; Miller \& Meloy, 2006; Schwartz, 2005; Swan \& Snow, 2006).

\section{Canada's Ongoing Men's/Fathers' Rights Protest Cycle}

The three policy and protest events examined below are situated within a larger protest cycle centered on fathers' advocates' efforts to secure father-friendly reforms to custody and access provisions of the 1985 Divorce Act. This act instituted Canada's prevailing no-fault, child's-best-interests family law regime (LeBourdais 
\& Lapierre-Adamcyk, 2004; see also Boyd \& Young, 2002). Largely in response to fathers'-rights lobbying, the Liberal government of Jean Chrétien introduced what was to be a new Divorce Act in December 2002 as Bill C22 (see history and legislative summary in Department of Justice Canada, 2006). This bill introduced joint parental responsibility as a substitute for child custody, in deference to fathers' rights concerns, but elaborated child's-best-interests considerations to include not only the history of care of the child but also family violence, in deference to feminist concerns, a compromise that fathers' advocates denounced as a betrayal (Boyd, 2003; Mann, 2005). Bill 117 died, however, when Jean Chrétien resigned as prime minister in November 2003, leaving divorce reform and other unfinished business to future governments, which have yet to take up the contentious issue of divorce law reform.

The pivotal moment in this unfinished policy and protest cycle, to date, was the furiously angry "gender war zone" (Bala, 1999) of the1998 Special Joint Committee Hearings on Child Custody and Access (hereafter SJC), at which more than 500 Canadians testified (Mann, 2005). Senator Anne Cools, who has supported men's rights since the 1980s (Boyd \& Young , 2002), played a dominant role. With the support of the SJC cochair MP (Member of Parliament) Roger Gallaway, she lauded the testimony of representatives of 69 pro-men's groups, entering into evidence lists of family violence studies that men's advocates' maintain support their claims of victimization by women, antidomestic violence services, and the divorce industry. At the same time, she "cross-examined" the testimonies of representatives of 44 antidomestic violence agencies, who by and large managed to remain civil (see also Laing, 1999).

The repertoire of experience, knowledge, and claims-making forged in the SJC and a subsequent set of Federal-Provincial-Territorial consultations (Mann, 2005) shaped fathers' advocates', feminists', and officials' expectations and actions in the policy moments to which this article now turns. This repertoire includes journalistsubstantiated (McIlroy, 1998) evidence that at the SJC, some convicted domestic violence abusers presented themselves as victims; that during and outside the SJC hearings, some men's rights advocates heckled or indeed harassed anti-domestic violence advocates; and that Senator Anne Cools encouraged and participated in their attacks on feminism, domestic violence services, and the family law and criminal justice systems (Mann, 2005, Bala, 1999; Laing, 1999; Rhoades \& Boyd, 2006).

In the following discussion of men's rights and anti-domestic violence advocates' interactions with officials in Ontario and Alberta domestic violence policy forums, the analytic focus is not with what discursive actions or repertoires mean, theoretically or assumedly to speakers or audiences. It is rather with how discursive enactments link to men's advocates' and feminists' ongoing and past efforts to forge understandings, mobilize sympathies, and shape or reshape policy. This is to say, my analytic concern is the "rhetorics of contestation" (Rose, 1999, p. 281) and what these reveal about the play of power among men's advocates, feminists, and officials 
(see also Barnes et al., 2004; Hunt, 1997, 1999; Hunt \& Wickham, 1994; Mautner, 2005; Rose \& Valverde, 1998).

\section{The Ontario Domestic Violence Protection Act, Bill 117}

The Ontario government under Progressive Conservative premier Mike Harris introduced Bill 117 at the height of public concern over a series of spousal murders, homicide-suicides, and familicides that the media, women's groups, and opposition party members linked to the Harris government's cutbacks to social welfare and domestic violence services. Modeled after similar legislation in other Canadian and U.S. jurisdictions (Roberts, 2002), the bill's key innovation was an enhanced restraining order that was to be available on a 24-7 basis, designed to allow a victim to temporarily expel an abusive partner from a family residence and secure bank accounts and credit cards to meet household needs. As stated by the MPP (member of provincial parliament) who introduced the bill to the Ontario Legislature on behalf of the solicitor general, the government's aim was to protect victims, and especially children, from a "disturbing and insidious crime" that "in the broadest sense [is] against the foundation of an orderly society," a crime for which "all of us as legislators, neighbours, fathers, mothers, and citizens of Ontario," are responsible (MPP Gerry Martiniuk [Progressive Conservative]), Legislative Assembly of Ontario, 2000b).

The Standing Committee on Justice and Social Policy set aside 3 days for citizen input (October 24, 30, and 31, 2000). Over these 3 days, 13 advocates for men testified; almost all had testified before the 1998 SJC or represented a group that did, including Senator Anne Cools and the SJC cochair MP Roger Gallaway. ${ }^{3}$ In contrast, only 1 of 15 anti-domestic violence advocates represented a group that participated in this prior policy and protest moment. ${ }^{4}$ All were assumedly aware, however, of the substantive focus and dynamics of men's advocates', feminists', and officials' interactions in this event, if not through face to face discussions, then certainly through newspaper and especially Web site commentary (see SJC links on advocacy Web sites listed in the references; see also Mann, 2005).

First to present on October 24, 2000, was Butch Windsor of Equal Parents of Canada (EPC). His testimony introduced themes that run through men's advocates' testimony and Web site commentary, namely, the unfairness or indeed the "ugliness of the current divorce laws"; women's rampant use of false allegations; women's economic exploitation of men; the refusal of the federal and provincial government to fund men's groups, or alternately, unfair funding of women's groups through Status of Women; and men's groups' exclusion from policy making:

Butch Windsor, EPC (October 24, 2000): I am a parent who, because of the ugliness of the current divorce laws, has made an investment of my time and skills to help others. My goal is to prevent false allegations. .. . Unfortunately, without government funding, 
it is difficult to intervene prior to the allegations. . . The use of false allegations of child abuse and spousal abuse is [the] ultimate weapon... .

Ten years ago, when counseling fathers, we had a standard caution. We told them how on a Friday evening when they arrive home from work, the wife will pick an argument with them and call the police so they can be taken away on the claim of abuse. On Monday morning, while they are arranging bail, their partner is in family court taking the house, the children and the bank account. ...

[T]his bill was developed through public consultations with shelter organizations, transition houses, hospitals representing the female side of the issue, and, as you detected, no male organizations. Being allowed to the table is part of the solution.

The Bill 117 Committee members' response to Windsor's testimony is captured in comments by the two opposition MPPs who responded. It is important to note that no other committee members asked questions or commented on Windsor's presentation, despite his allowing sufficient time. Liberal MPPs Bountrogianne and Bryant therefore appear to express the opinion of the committee as a whole, that in a democracy everyone has a right to be heard but that dissonant testimony (see Koopmans \& Olzak, 2004, p. 205), extraneous to "the reality" that a significant number of women are victims of domestic homicide annually in Ontario, would be "taken under advisement":

Marie Bountrogianni, Liberal MPP (October 24, 2000): Rarely do we get presenters who unite us ... the reality is that 44 women were killed in Ontario last year, and this bill is attempting — attempting - to begin to look at that problem. . . It's a democracy. Your views are taken under advisement, but I'm being very honest with you: I disagree with your premises.

Michael Bryant, Liberal MPP (October 24, 2000): Your research is wrong; your facts are wrong. You are spreading untruths. . . . This is a democracy. Your arguments have created a dialogue, and I'd just echo my colleague's comments. I would hope that we are united in opposition against your particular viewpoint, sir.

Donna Hansen and Joanne Krauser copresented immediately after Windsor on behalf of the Alliance of Second Stage Housing Programs. Their presentation focused on the importance of a holistic rather than strictly justice-focused domestic violence prevention strategy, the central theme and focus of anti-domestic violence advocates' testimony across the 3 days. Specifically, Hansen and Krauser praised the government for introducing Bill 117 but stressed the importance of shelters, in particular second-stage housing (i.e., not just short-term emergency housing), in protecting women and children. As part of this, they cited their group's participation in the "128 member agencies of the Cross-Sectoral Violence Against Women Strategy 
Group," which sought full restoration of funding for second-stage housing and other abused women support services. In the engaged dialogue with MPPs across party lines that followed their presentation, committee members sought details on how the Harris government's cuts to and reallocations of domestic violence funding affected women like Jillian Hadley, whose murder is the focus of the coroner inquest addressed below.

Eric Tarkington of Human Equality Action Research Team, who more commonly testified on behalf of EPC, followed Hansen and Krauser (Legislative Assembly of Ontario, 2000c, October 24). This long-time men's advocate prefaced his comments on the "draconian" nature of Bill 117 with "You probably think I'm the devil incarnate." His main points were that "the rate of real domestic violence is very low," that "women do more than men," and that false allegations would "be propelled" were the bill to pass into law. Warning that the men's movement "is reaching political age," Tarkington denounced the federal and provincial governments for funding "hatred of men" through Status of Women and the Ontario Women's Directorate, each of which he emphasized "exists and costs millions of dollars every year" (Legislative Assembly of Ontario, 2000c, October 24). Tarkington allowed ample time for questioning and comment, but only one committee member responded, Progressive Conservative MPP Tina Molinari. She assured Tarkington that the intent of the bill was "not in any way to punish or to be unfair to men" but rather "to enforce some of the protection for those who are experiencing violence." She then asked him to clarify what he meant in saying the "real incidence of domestic violence is low" and specifically what in the definition of domestic violence covered by the bill was not, in his view, domestic violence.

With two exceptions-lawyer Walter Fox on October 24, 2000, who was to represent Fathers Are Capable Too (FACT) at the upcoming Hadley Coroner Inquest, and MP Gallaway and Senator Cools, who copresented on October 31, 2000-the testimony of all remaining men's advocates elicited silence. This was either because presenters took up the full 20 minutes allotted, leaving no time for questions or comment (Brian Jenkins, a FACT affiliate Gene Colosimo, FACT; Grant Wilson, Canadian Children's Rights Council; Maxine Brandon, Mothers for Kids; David Osterman, Freedom for Kids; and Dori Gospodaric, Second Spouses), or because members of the committee declined to question or comment (see Peter Cornakovic, FACT, and Bill Flores, Children's Voice). It is important to note that in contrast to the 1998 SJC, no official "played to the men's rights gallery" (Rhoades \& Boyd, 2006, p. 134; see also Bala, 1999; Laing, 1999; Mann, 2005). No member of the committee concurred that "restraining orders are nuclear weapons in Family Court" (Erik Tarkington), or that false allegations are "rampant" and the "ultimate weapon" of women and "the divorce industry" (Butch Windsor, Erik Tarkington, Brian Jenkins, Peter Cornakovic, Bill Flores, Walter Fox, Grant Wilson, Maxine Brandon, Dori Gospodaric, Senator Anne Cools). None lauded assertions that men are equally or more victimized by domestic violence than are women (Eric Tarkington, Brian 
Jenkins, Peter Cornakovic, Grant Wilson, Doris Gospodaric, Senator Anne Cools). None joined in denunciations of feminism and the funding of victim services through Status of Women (Butch Windsor, Eric Tarkington, Peter Colosimo, Brian Jenkins, Bill Flores, Doris Gospodaric, Senator Anne Cools, and by implication Walter Fox). Finally, none sympathized with the claim that tragedies like the Hadley murder-suicide "can only be seen as suicides first" and that such tragedies occur "because we don't care about men" (David Osterman).

A very different tone and rhetorical dynamic marked the testimony of antidomestic violence advocates. From Donna Hansen and Joanne Krauser forward, anti-domestic violence advocates portrayed their aims as consonant with the Bill 117 objective to improve protections for domestic violence victims (again, see Koopmans \& Olzak, 2004, p. 205). The presentation of Eileen Morrow of the Ontario Association of Interval and Transition Houses on October 30, 2000, exemplifies the respectful and collaborative stance these assumed feminists adopted. As was the case of anti-domestic violence advocates' generally, Morrow mixed support for Bill 117 with constructive criticism on how to go beyond justice measures to fully address the complexity of domestic violence (see also Beryl Tsang, CrossSectoral Violence Against Women Strategy Group; Vivian Green, Woman Abuse Council; Dorothy Bakos, Family Service Association; Marion Wright, Woman's Place of St. Catharine's; and Pamela Cross, Metropolitan Action Committee on Violence Against Women and Children:

Eileen Morrow, OAITH: I'd like to begin by speaking specifically to the letter of the bill and to support some of the positive points within that limited framework. We're happy to see that the definition of applicants has been expanded to allow women in a range of relationships, including same-sex relationships and dating relationships, to access this order. ... We are pleased. . . However, we have a couple of suggestions for amendments or recommendations for implementation. . . . We need more than the lawand-order initiatives . . . I ask that you address not only the justice issues but also the social policy and social development measures necessary to truly respond to violence against women. (Legislative Assembly of Ontario, 2000c, October 30)

Though several clearly identify with feminism on Web sites and in other forums, not one anti-domestic violence representative referred to men's advocacy or feminism in her Bill 117 testimony (Legislative Assembly of Ontario, 2000c). Moreover, although Bev Tsang did state that "all women"- marginalized women in particular- "live with the threat of male violence," and cited evidence in support of this, not one stated or implied that all men are abusive or otherwise indicated hatred of men. Instead, these alleged "radical feminists" (Bill Flores' characterization of woman abuse advocates on October 24, 2000) located feminist understandings within prevailing "discursive opportunity structures" (Ferree, 2003, p. 308). That is, they identified Bill 117 as "a step in the right direction" (Bev Tsang, October 30, 2000) in 
meeting "the universal interest that exists in providing women victims of abuse with tools necessary to keep themselves safe and gain necessary supports" (Vivian Green, October 30, 2000). Their insistence on the importance of shelters and other social supports built on this assumed common interest. As important as the framing of their arguments, however, was the timing of their testimony to allow for questions and discussion; and in each instance, one or more MPPs engaged in respectful and substantive dialogue with these self-identified "partners" (Dorothy Bakos, October 30, 2000) in domestic violence intervention (on citizen-official dialogue in deliberative forums, see Barnes et al., 2004).

For reasons largely extraneous to men's rights and feminist lobbying, the Ontario Legislature passed but did not subsequently enact Bill 117 (Roberts, 2002). Instead, a year after the hearings, it held the Hadley Coroner Inquest, a policy event that entered into men's advocacy as a key protest moment due to the chief coroner's decision to grant FACT official standing. That is, the chief coroner of Ontario gave this self-proclaimed moderate men's group (FACT Web site mission statement) the opportunity to demonstrate its ability, willingness, and suitability to join in efforts to develop effective domestic violence policies to help save lives.

\section{The Hadley Coroner Inquest}

The Hadley Coroner Inquest was one of three high-profile inquests into murdersuicides and familicides held by the Government of Ontario under controversial neoconservative premier Mike Harris between 2000 and 2001 (Domestic Violence Death Review Committee, 2003). As a consequence of is official standing, FACT and its lawyer, Bill 117 participant Walter Fox, received extensive media attention. This media attention is captured in FACT's Web site archive of 126 articles from the Ottawa Citizen, the Toronto Star, the Globe and Mail, the National Post, and smaller news media that document the 53 days of public testimony on the failure of Canada's justice system to effectively intervene into Gillian and Ralph Hadley's terrifying "dance of death" (Senator Cools's Bill 117 characterization of domestic violence). This "dance" ended on June 20, 2000, when Gillian Hadley was dragged naked into the front yard of their house by Ralph Hadley, against whom she had a restraining order. He allowed her to pass their 11-month-old son into the hands of a neighbor, and then dragged her back into the house where he murdered her and killed himself.

FACT's media archive on the inquest capture how this self-identified moderate voice for men and fathers viewed and used the opportunity the chief coroner afforded it. The archive opens with a five-part series by Ottawa Citizen columnist Dave Brown (December 4 through December 8, 2001), through which FACT introduces the inquest. Brown's first article (2001a) focuses on the need to challenge moral panic (citing Fekete, 1994) over domestic violence spawned by feminism, and the invasive, disempowering, and dishonest industry or indeed "cult" of domestic violence services instituted in the wake of this panic. It recounts FACT's 
"groundbreaking" role in advancing a more "balanced perspective" at the Hadley Inquest, and outlines lawyer Walter Fox's plan to use the inquest to debunk the "bible" of the women's anti-violence movement, the Report of the Canadian Panel on Violence Against Women (1993). In the second article, Brown (2001b) uses an anecdotal account of a reformed female abuser to advance the argument that no government-sponsored support or protection for abused men exists in Canada. In the third article, Brown (2001c) denounces domestic violence victim services, which he alleges function to invade and destroy families. In the fourth article (2001d), he targets Peter Jaffe (of Jaffe \& Crooks, 2004), who he labels a "slick" "social scientist evangelist" who "pitches the religion of violence against women ... [across] North America." In the fifth article, Brown (2001e) rants against the \$145 million a year the Ontario government then spent "on programs associated with preventing domestic violence and punishing its perpetrators," and denounces newly introduced domestic violence courts, which he asserts "violate the Charter rights of half the population - the male half." He concludes with a call for men, and all taxpayers, to question Ontario's and Canada's domestic violence policies.

Following Brown's five-part series is what should be the lead article, were the archive in reverse chronological order (the remainder of the archive is). This article is Brown's (2002) denunciation of the Hadley jury's recommendations. It includes a repeat denunciation of the "CanPan report" and Peter Jaffe, "himself a member of the 1992-93 Canadian Panel on Violence." Brown ends with a reminder that the Hadley Inquest was the first time a men's group was accorded an official voice in efforts to forge policy on domestic violence in Canada, and a note of admiration for Walter Fox's role in advancing men's interests in this "historic moment."

The remainder of the archive contains articles that for the most part ignore both FACT and Fox. Two Toronto Star articles, however, that FACT prefaces with extensive red-ink commentary, express strong disapproval of both. Appearing first in the reverse chronological listing is now retired feminist-columnist Michelle Landsberg's (2002) account of how FACT, and therefore Fox, obtained standing at the inquest. After citing the chief coroner's written rationale, Landsberg provides insight into Fox's views by recounting details of his personal history and examples of his opinions on domestic violence and feminism gleaned from court records of his own divorce litigation and his testimony before the SJC, in which Fox compares feminism to McCarthyism and Nazism:

The coroner explained in writing that although FACT had no direct involvement with Ralph or Gillian Hadley, it was a special interest group with a "unique perspective" that wished to "contribute to recommendations that might prevent similar tragedies." Hence we had Walter Fox, a criminal lawyer and FACT's counsel at the inquest. . . . In 1998 [before the SJC] Fox spoke out bitterly about the proceedings of family courts. . . . "Feminism," he told the committee, "has come to take on the structure of McCarthyism . . . I don't want to equate feminism with Nazism . . . but . . ..” (Landsberg, 2002) 
The second critical article is by Jim Coyle (2001), who FACT in its red-ink preface labels "a Landsberg wannabe." In the article, Coyle identifies "two streams of anger" at the inquest, a stream of "understandable indignation at watching bodies of women murdered by partners pile up in recent years," and an "inane to asinine," "bitter," "alarming," and "possibly dangerous" anger manifested in "belittlement" of all opposing views as "ultra-radical feminist." Coyle notes that these views, and anger, emanate simultaneously from "FACT's lawyer Walter Fox ... [and] the FACT website."

FACT's media archive does not provide evidence into how the majority of readers and politicians viewed the "epic social debate" (Brown, 2001d) between fathers' advocates and advocates for abused women hosted by the chief coroner of Ontario in 2001. Nor does this archive address how anti-domestic violence advocates responded to FACT or Fox. The five-member jury, however, clearly came down on the side of victims and their needs. According to Globe and Mail columnist Gay Abbate (2002), who does not cite FACT in any of the articles she authored, "Parties to the inquest applauded the [jury's] recommendations." Among these was the man whose wife saved the Hadleys' infant son:

John Wallace [saw] Mr. Hadley drag his naked wife outside their house at gunpoint. . . Mr. Wallace's wife, Ana, snatched the Hadleys' 11-month-old child to safety. But he could not stop Mr. Hadley from dragging his wife into the house and to her death. . . . Yesterday, Mr. Wallace urged everyone to support the recommendations in order to help the 40 women who are killed by abusive partners each year in Ontario. ... "I saw a lady fight for her life that day. I heard her groan when she was dragged back into the house.

She knew it was all over." (Abbate, 2002)

With the exception of Brown (2002), all the archived articles that comment on the jury's recommendations support them, as subsequently did police associations, various professional bodies, and women's groups, leaving men's advocates alone in opposition (based on a 10-page Google search, November 2005). The Harris government responded by establishing a Domestic Violence Death Review Committee (2003) to review domestic homicides on an annual basis, modeled after precedents in the United States; expanded specialized domestic violence courts; and initiated development of the Ontario Domestic Assault Risk Assessment. FACT and other men's advocacy groups remain opposed to these measures on the grounds that they reflect and perpetuate "purposeful bias," that "prevention of such a rare occurrence [as domestic homicide] is simply not possible," and that it is "the 'enforcement' system in Ontario [that] kills, by draining the hope of men" (FACT Web site news release in response to the Domestic Violence Death Review Committee, 2003, authored by Bill 117 participant Brian Jenkins, April 2, 2004). The current government under Liberal premier Dalton McGuinty (2003-present) retains all these Harris government-sponsored measures as part of its Ontario Domestic Violence Action Plan, which it describes as a new approach to ending male violence against women 
and the sexism at its root (Government of Ontario, 2005). In sum, Ontario has attempted to include the voice and perspectives of men's advocates in domestic violence policy making, but it is those who believe in and support possibilities of forging solutions who shape policy outcomes.

\section{The Alberta Roundtable on Family Violence and Bullying}

The Alberta Roundtable on Family Violence and Bullying was held in May 2004, the culmination of a larger consultation process convened under the leadership of Progressive Conservative premier Ralph Klein. The consultation responded simultaneously to mounting public concern about bullying in schools and to a wave of family-related homicides that included the murder of a 3-year-old child who had informed daycare staff that he and his mother were going to "get killed'd" [sic] shortly before his father in fact killed them (Legislative Assembly of Alberta, February 24, 2004, Honourable Iris Evans, Minister of Children's Services).

The Alberta government invited multiple "communities" with the stated intention of providing "an opportunity for meaningful dialogue and the development of a shared vision for the elimination of family violence and bullying" (Government of Alberta, 2004a, p. 9). Approximately 3,000 Albertans participated through an online workbook, formal briefs, provincewide focus groups, and the roundtable itself. Roundtable texts (Government of Alberta, 2004a, 2004b, 2004c, 2004d) emphasize the pervasive and devastating effects of family violence and bullying on all people and all communities, the interrelationship of family violence and bullying, the power and control dynamic that drives both, and the causal role of structural inequalities and associated values in fostering both. They also emphasize the importance of sound evidence and the responsibility of all citizens to partner to protect children and build a less violent society.

The diversity of participating voices is exemplified in representation at the focus groups, whose feedback is cited in Alberta's proposed and final Action Plan (Government of Alberta, 2004b, 2004c). It is noteworthy that the 32 individuals who represented 4 men's groups and the 107 individuals who represented 6 women's groups were outnumbered by 567 individuals representing 23 Aboriginal groups, faith groups, the military, an elder abuse group, a group representing gay, lesbian, and transgendered people, and a group representing persons exploited through prostitution, among others (Government of Alberta, 2004d, p. 5; see also briefs and resources posted on ACAV, Alberta's Action Committee Against Violence). Heeding this multitude of voices, roundtable texts acknowledge the importance of providing equitable though explicitly not equal access to services to all victims (Government of Alberta, 2004b, 2004c). At the same time, drawing on Statistics Canada reports and the research literature, they emphasize that women and children are the principle victims of family violence, and review evidence on the scope, dynamics, and social distribution of women's victimization. Moreover, roundtable texts reproduce 
data that identify Alberta as having the highest rate of spousal violence and homicide in Canada, and Aboriginal people, Aboriginal women and girls especially, as being particularly at risk for spousal homicide, severe partner violence, sexual abuse, and sexual exploitation (Government of Alberta, 2004b, 2004c, 2004d).

Consistent with a Canada-wide shift to a focus on children (Dobrowolsky \& Jenson, 2004), the final roundtable report mutes or "obscures" (National Council of Women of Canada, n.d.) consideration of gender while prioritizing the needs and interests of children. Definitions and solutions, however, remain consistent with understanding and recommendations of anti-domestic violence service providers. These include a public education campaign to raise awareness of the extent, seriousness, and interrelationship of family violence and bullying; enhancing victim supports, including financial aid to victims fleeing abuse; expanding domestic violence courts and unified family courts; developing and using risk assessment screening tools; establishing a Family Violence Death Review Committee on the Ontario model; and developing and implementing better protocol and services to protect children from experiencing and witnessing family violence in the context of custody and access disputes (Government of Alberta, 2004b).

This Alberta policy process entered into the repertoire of fathers' rights activism through Web site rants that identify the roundtable initiative as "man hating" and "misandrist," and that link it to a feminist-instigated "holocaust" or "patricaust" on men (Fathers for Life Web site; see also Web sites of B.C. Fathers, Family of Men, Fathers Canada 4 Justice, among others). Accompanying these critiques are pasteups or links to an Internet-disseminated article titled "Institutional Resistance to Acknowledging Intimate Male Abuse" that researcher Eugen Lupri (2004) presented at a Counter-Roundtable Conference that he and other men's advocates convened in Calgary in May 2007 to express their dissatisfaction with the roundtable process. Using decidedly less vitriolic language than the Web sites cited above, Lupri denounces the Roundtable process as an attempt to appear gender neutral and inclusive while advancing the same familiar "feminist definitions." Comparing the roundtable process to his experience coauthoring an article on men's victimization for Health Canada, published by the National Clearinghouse on Family Violence (Lupri \& Grandin, 2004), he argues that the Canadian government and "agency departments" within the FVI only pretend to listen to the male voice, and that in reality it stifles or "edits out" evidence on the reality of male victimization.

Recognizing that at the Alberta roundtable, men's voices were effectively outnumbered, and not just by feminists, Lupri (2004) ignores the Alberta government's commitment to ensure that all victims are afforded equitable access to services. Instead of engaging with the question of what would be equitable or sufficient to meet the needs of victimized men, he asserts that feminism's "interpretive politics" and its "strategy to construct intimate violence as a gender issue has worked." Lupri concludes with a call for sustained political opposition to "unconscionable" and "enduring depiction of men as oppressors and women as victims": 
To exclude male victims completely from receiving similar special services as female victims receive is untenable, discriminatory and unconscionable. These notions and tactics can and must be challenged by all of us, based on the overwhelming evidence that is available. Doing so will require dedication, resiliency, and persistent support of the cause. (Unnumbered final page)

In June 2006, Lupri's (2004) article was available on 11 men's rights Web sites, including 8 Canadian sites, a German site, an Irish site, and a U.K. site. In addition, it was posted or cited on 4 academic, research, or informational Web sites, one of which posted a prepublication version of Straus's contribution to the Violence Against Women Special Issue on gender symmetry. In this article, Straus (2006) introduces Lupri's argument on government resistance to research on gender symmetry into scholarly discourse. ${ }^{6}$ Across these Web sources, Lupri's article is used to reinforce assertions that feminists falsely frame domestic or family violence as a gender issue rather than a human problem, and that feminists and governments influenced by feminists suppress research on women's violence and men's victimization. To bolster these arguments, Straus (2006) incorporates Lupri's rhetoric into his own two-and-a-half-decade-long critique of feminism (see Breines \& Gordon, 1983). He asserts that a "small but increasingly influential men's movement is starting to change the political climate" and that this change in climate will eventually remove the "politically based blockage" of gender-inclusive research and programming that feminism has imposed (2006, p. 1091).

\section{Discussion}

The three theoretical perspectives outlined at the beginning of this article provide insights into the fragile and contingent success of feminists' efforts to defend gender-sensitive domestic violence interventions in the face of men's rights backlash in Ontario and Alberta in the first few years of the 21st century. First, from a governance perspective, these three policy moments draw on and reproduce the historically contingent social and political power of feminism and men's rights in Canada's new millennium citizenship regime and gender order. Feminism helped shape this regime and order through its participation in the 1970s established women's policy machinery of Status of Women Canada (Weldon, 2002). The very Constitution of Canada bears its imprint in Sections 15 and 28 of the Charter of Rights and Freedoms. Building on this foundation, feminism has secured an official, or quasiofficial, position within Canada's multipartner FVI. Through the FVI, it has helped to advance understandings and develop interventions for nearly 20 years, funding research, service delivery, and advocacy that link intimate violence against women with historically constituted practices of gender oppression. Beyond gender, it has explored the ways intimate battering intersects with oppressions rooted in poverty, 
ethnicity, disability, sexual orientation, and other statuses and problems, and has joined with those advancing the needs of these constituencies to forge change. Indeed, feminism's commitment to women is part of its commitment to the eradication, or at least the amelioration, of oppression and abuse of human subjects, period. It is part of feminism's official commitment to caring and social justice (Taylor \& Rupp, 2002; see also Carney, 2003; Shaw \& Andrew, 2005; Snider, 1998).

In contrast, since its emergence in the 1980s, men's rights advocacy has opposed efforts to foster women's autonomy and put a stop to their victimization on the grounds that gender-sensitive domestic-violence and family-law policies perpetrate bias and hatred against men, driving them to violence, homicide, and suicide (Bertoia \& Drakich, 1993; Boyd \& Young, 2002; Crean, 1988). These claims have not been without impact (Minaker \& Snider 2006). Indeed, especially in family law arenas, men's advocates' arguments have shaped legislative compromises (Boyd, 2003; Boyd \& Young, 2002; Mann, 2005; Rhoades \& Boyd, 2006). Thus, although men's rights advocacy has not achieved its goal to level or equalize the playing field for men by eliminating protections and supports for abused women, it has succeeded in raising questions about the justice of these policies in a series of high-profile government forums, which has produced a new official discourse on abused men or husbands (e.g., Lupri \& Grandin, 2004; Tutty, 1999).

Second, poststructural perspectives on the discursive constitution of emotional and cognitive aspects of subjectivity and its deployment in interpersonal and collective contexts offer insights into these processes and their inevitably incomplete outcomes (Hunt \& Wickham, 1994; see also Cooper, 1994; Taylor \& Whittier, 1995; Towns \& Adams, 2000; Weedon, 1987). Drawing on poststructural understandings of the relational nature of power, Canadian feminism's successes flow from its willingness and ability to "rethink" (Dobash \& Dobash, 2004) and reconstitute its political subjectivity and self-presentation in ways that reflect the repudiation of power and control that is central to what feminism espouses (Snider, 1998; Taylor \& Rupp, 2002). In Canada and beyond, feminism has struggled to work out divisions and differences within and across theoretical, governmental, and other divides, listening to the diversity of women's voices and concerns (Burgess-Proctor, 2006; Potter, 2006). It has secured its sanity in the face of hostile threats (Dilorio \& Nusbaumer, 1993). It has reshaped its rhetoric to fit the contours of bureaucratic and public communication (Eisenstein, 1996; Walker, 1990; Weldon, 2002). It has creatively confronted and incorporated methods and findings that challenge gender-specific analyses of domestic violence (Anderson, 2005, Johnson, 2006; Mann, 2000; Miller, 2006; Potter, 2006; Schwartz, 2005). And it has productively navigated clashes in values and related obstacles to collaboration and partnering (McMahon \& Pence, 2003). It has not, however, lost sight of its goal to eradicate the economic, social, political, and intimate oppression of women as women. Rather, it has replaced strategies or tactics that do not advance this goal with those that do, expanding its toolkit (Swidler, 1995) to include a multiplicity of subject locations, perspectives, and 
methodologies that are consonant with prevailing discursive and institutional opportunity structures (Carney, 2003; Ferree, 2003; Koopmans \& Olzak, 2004). These efforts have reshaped, and continue to reshape, the self-understandings of anti-domestic violence researchers and advocates, as well as the self-identity of feminism itself.

Men's advocates, and the family violence researchers on whose work they draw, have also learned. However, men's advocates have largely learned that although what they are doing garners attention and the support of at least some officials, it is not enough. Determined to force the government as a whole to accept the truth that men are equally, as opposed to also, domestic violence victims, they have intensified their attacks on feminism and the policies feminism supports. Armed with findings gleamed from Martin Fiebert's (2006) constantly updated, Internet-disseminated, annotated bibliography of research on gender symmetry, men's advocates deploy a rhetoric of hatred and victimization that they have honed through internationally linked Web site diatribes against feminism, ex-wives, child support, shelters, and the family law and criminal justice systems (Bouchard et al., 2003; Mann, 2005; Minaker \& Snider, 2006). Inflamed by the stories they tell each other and themselves, men's advocates demand entrance into policy deliberations. They refuse, however, to abide by norms of "mutually respectful" policy dialogue (Department of Justice Canada, 2005), and thus project not consonance but dissonance with governmental goals (Koopmans \& Olzak, 2004). Again and again they conclude and proclaim that the system is biased and that feminism is behind a pervasive and persistent assault on men and "cover-up" (Straus 2006, p. 1088) of men's victimization.

Finally, social movement theory directs attention to the ways social movement and countermovement interactions shape responses of officials to the play of emotions and their deployment in these processes (Aminzade \& McAdam, 2002; Barnes et al., 2004; Einwohner, 2002; Mann, 2002; McCaffrey \& Keys, 2000; Rohlinger, 2002; Swidler, 1995; Tarrow, 1998; Taylor \& Rupp, 2002; Taylor \& Whittier, 1995; Whittier, 2001). From the 1980s forward, men's advocates have heaped scorn on feminism in public forums (Boyd \& Young, 2002). Feminism, in contrast, has endeavored to refrain from reciprocating vitriol (Mann, 2005; Boyd \& Young, 2002; see also the Bill 117 hearings). In public hearings, and also on their Web sites, feminists have cultivated the reasonable and respectful front that is a requirement for participation in policy arenas (Department of Justice Canada, 2005; see also Barnes et al., 2004), accompanied by a determined focus on gender-specific dynamics and what is needed to reduce women's and children's victimization and vulnerability. As do feminists generally, Canadian anti-domestic violence researchers and advocates acknowledge that men can also be victims, and endorse supports and protections for those who are (e.g., Federal-Provincial-Territorial Ministries, 2002; Tutty, 1999). Feminists stand firm, however, that women and children are the primary victims, a stand that is supported by the "annual pile up" (Coyle, 2001) of women and children murdered by intimate partners and fathers in Canada (AuCoin, 2005; Ogrodnik, 2006). 
The Bill 117 hearings, the Hadley Coroner Inquest, and the Alberta Roundtable were each convened in response to public concern over precisely this manifestation of the domestic violence problem. In each instance, men's advocates opted to grandstand, denounce, belittle, ridicule, and misrepresent. They opposed risk-assessment tools, restraining orders, domestic violence courts, support services for female victims, and child's-best-interest presumptions. At the same time, they insisted that men are equally victimized and that men deserve and require special services and protections equal to those that are in place for women. Perhaps most important, in each forum men's advocates directed their energies more to discrediting their selfproclaimed feminist enemy than to exploring or advancing ways men and fathers could contribute to collective efforts to solve the domestic violence problem.

A major outcome of this movement/countermovement dance is that feminist anti-domestic violence advocates tend to be taken seriously in domestic violence policy forums, even as the focus of government action shifts from violence against women, to intimate partners, to children (Dobrowolsky \& Jenson, 2004). Conversely, whereas men's advocates elicit official acknowledgement that men are also domestic violence victims (AuCoin 2005; Federal-Provincial-Territorial Ministries, 2002; Government of Alberta, 2004a; Lupri \& Grandin, 2004; Ogrodnik, 2006; Public Health Agency of Canada, 2004, 2006; Tutty, 1999), they have not succeeded in constituting men as equal victims. Whether explicitly, as in the Ontario Domestic Violence Action Plan (Government of Ontario, 2005), or implicitly, as in the Alberta Action Plan (Government of Alberta, 2004b), government-sponsored interventions retain their focus on preventing debilitating and lethal forms of domestic violence, forms of violence that disproportionately target women and children as victims. Otherwise stated, practices of participatory democracy have afforded feminists and men's advocates a place at the various roundtables, hearings, and inquests in which domestic violence polices are forged, alongside advocates for other constituencies and individuals who claim no constituency other than that of citizen. To be taken seriously, however, participants must demonstrate willingness and ability to participate in the new democratized gender order that underpins the FVI and associated provincial-territorial initiatives. They must demonstrate that they recognize the scope and seriousness of the domestic violence problem, that they eschew violence and bullying absolutely, that they respect difference, that they recognize each other as equals, and that they are willing to prioritize children. Finally, they must demonstrate commitment to collective efforts to eradicate social harm through partnership and dialogue. They must show that they are willing and able to play the communitycivility game mandated for our advanced liberal moment (Barnes et al., 2004; Cherlin, 2004; Dobrowolsky \& Jenson, 2004; Hunt, 1997, 1999; Rose, 1999). Building on their respective identities and deploying their respective discourses, feminist anti-domestic violence advocates repeatedly do so; men's advocates, in contrast, repeatedly do not. 


\section{Conclusion}

The aim of this article is to contribute to understandings on how to maintain a gendered focus in domestic violence strategies and services in the face of an increasingly vocal and influential men's rights backlash against feminism and progressive movements generally. In Canada, as in Australia and other Western jurisdictions, government support for women's services has diminished in a context of intensified antifeminist lobbying (Chesney-Lind, 2006; Jaffe \& Crooks, 2004; Minaker \& Snider, 2006; Morrow et al., 2004; Rhoades \& Boyd, 2006; Weldon, 2002). These developments lend poignancy to this article's effort to critically examine feminism's contingent and fragile success in withstanding men's advocates' efforts to disqualify and disband domestic violence services and strategies that protect women and children in the name of gender equality. ${ }^{7}$ Historically, domestic violence policies are most developed in jurisdictions that have a women's policy machinery (Weldon, 2002). In Canada, as elsewhere, the dismantling of these machineries presents a formidable challenge to the anti-domestic violence movement. However, as Laurel Weldon (2002) observes, a strong women's movement is at the foundation of women's policy machineries and is a precondition for their existence. For more than a century, feminism has worked with and for women and other marginalized constituencies to secure justice and equality (Taylor \& Rupp, 2002). It has conducted this work from positions inside and outside government. Careful analysis and diagnosis of how feminism has accomplished its successes and failures in specific instances provides our compass for the future. This article contributes to the project of further developing and applying this compass.

\section{Notes}

1. The Foucauldian construct reverse discourses refers to instances in which individuals and groups draw on the very vocabulary and categories that characterize them in dominant or other oppositional discourses to create an opposing view (Cooper, 1994; Weedon, 1987).

2. At the time of this writing, permanent Family Violence Initiative funding stands at $\$ 7$ million, down from a 1991 high of $\$ 136$ million (Morrow et al., 2004, p. 362). Based on a National Clearinghouse e-mail communication on April 11, 2006, \$250,000 of the Family Violence Initiative's \$7 million budget was administered through Status of Women, which received the smallest allocation of the seven partner agencies when the Stephan Harper Conservatives entered into power in January 2006.

3. Maxine Brandon of Mothers for Kids (Legislative Assembly of Ontario, 2000c, October 24) was the only men's advocate who did not participate in the 1998 Special Joint Committee Hearings on Child Custody and Access (SJC) hearings or who did not represent a group that had. The other 12 men's advocates were (a) Butch Windsor of Equal Parents of Canada (EPC), who represented Human Equality Action Research Team (HEART) before the SJC; (b) Eric Tarkington of HEART, who represented EPC before the SJC; (c) Brian Jenkins, (d) Peter Cornakovic, and (e) Gene Colosimo of Fathers Are Capable Too (FACT), represented by Malcolm Mansfield, Deborah Powell, and Greg Kershaw at the SJC; (f) Bill Flores of Children's Voice; (g) Grant Wilson of the Canadian Children's Rights Council, who represented Mississauga Children's Rights before the SJC; (h) David Osterman of Freedom for Kids, represented by 
Nicholas Kovats at the SJC; (i) Dori Gospodaric of Second Spouses; (j) lawyer Walter Fox, who claimed to represent only himself both at the Bill 117 hearings and before the SJC; and copresenting at the close of the final day of citizen input, (k) MP Roger Gallaway and (1) Senator Anne Cools.

4. Eileen Morrow of the Ontario Association of Interval and Transition Houses was the only Bill 117 participant or group (October 30, 2000) who testified before the 1998 SJC (March 31, 1998). The other 14 anti-domestic violence advocates, who commonly copresented, were (a) Donna Hansen and (b) Joanne Krauser of Alliance of Canadian Second Stage Housing Programs; (c) Scott Newark of the Office for Victims of Crime; (d) Vivien Green, (e) Suzanne Young, and (f) Sandra Booth-McKelvie of the Woman Abuse Council of Metropolitan Toronto; (g) Dorothy Bakos of the Family Service Association; (h) Beryl Tsang of the Cross-Sectoral Violence Against Women Strategy Group; (i) Marion Wright of Women's Place of St. Catharine's; (j) Deborah Sinclair, (k) Helen Brooks, (1) Kate Schillings, and (m) Donna Babbs of the Durham Region Custody and Access Project; and (n) Pamela Cross of the Metropolitan Action Committee on Violence Against Women and Children.

5. Eric Tarkington has advanced these arguments in Canadian policy arenas since the 1980s, typically as a spokesman for EPC (see Boyd \& Young, 2002, p. 45). Tarkington represented EPC before the 1998 SJC on March 31, 1998.

6. The assessment of the spread of "institutional resistance" analysis on men's rights and other Web sites is based on a 10-page Google search (that is, a search through 100 possible hits) by title and author conducted on June 21, 2006. As of that date, no feminist or anti-domestic violence Web site in Canada or beyond had taken note of the Counter-Roundtable Conference or Lupri's (2004) article. Three feminist Web sites did comment on the Alberta Roundtable, however (Alberta's Research and Education for Solutions to Violence and Abuse, Sexual Assault Centre of Edmonton, and National Council of Women of Canada).

7. Prime Minister Stephan Harper's Conservative government (elected January 2006) is currently endeavoring to reshape the citizenship regime that sets the rules for public participation in policy formation and the boundaries of citizen and state responsibilities in Canada. Despite its tenuous minority status, this government has drastically reduced funding for women's programs and progressive causes generally, to the applause of men's-rights and other right-leaning groups, and to the alarm of feminists (Ditchburn 2006a, 2006b).

\section{References}

Abbate, G. (2002, February 9). Jury calls for protection of women: Society in general shares responsibility for battered wife's death, panel decides. Globe and Mail. Retrieved February 12, 2007, from http://www.fact.on.ca/hadley/hadley_i.htm

Action Committee Against Violence Web site. (n.d.). http://www.acav.org/documents

Alberta Women's Issues Web site. (n.d.). http://www.cd.gov.ab.ca/helping_albertans/human_rights/

Almeida, P. D., \& Lichbach, M. I. (2003). To the Internet, from the Internet: Comparative media coverage of transnational protests. Mobilization, 8, 249-272.

Aminzade, R., \& McAdam, D. (2002). Emotions and contentious politics. Mobilization, 7, 107-109.

Anderson, K. L. (2005). Theorizing gender in intimate partner violence research. Sex Roles, 52, 853-865.

Anderson, K. L., \& Umberson, D. (2001). Gendering violence masculinity and power in men's accounts of domestic violence. Gender and Society, 15, 358-380.

AuCoin, K. (2005). Family violence in Canada: A statistical profile 2005. Ottawa: Canadian Centre for Justice Statistics. Retrieved February 12, 2007, from http://www.statcan.ca/english/freepub/85-224XIE/85-224-XIE2005000.pdf

Ayres, J. M. (1999). From the streets to the Internet: The cyber-diffusion of contention. Annals, 566, 132-143.

B.C. Fathers Web site. (n.d.). http://www.fathers.bc.ca 
Bala, N. (1999). A Report from Canada's 'gender war zone': Reforming the child-related provisions of the Divorce Act. Canadian Journal of Family Law, 16, 163-227.

Barnes, M., Newman, J., \& Sullivan, H. (2004). Power, participation and political renewal: Theoretical perspectives on public participation under New Labour in Britain. Social Politics, 11, 267-279.

Berns, N. (2004). Framing the victim: Domestic violence, media, and social problems. New York: Aldine de Gruyter.

Bertoia, C., \& Drakich, J. (1993). The fathers' rights movement: Contradictions in rhetoric and practice. Journal of Family Issues, 14, 592-615.

Blee, K. M. (2007). Ethnographies of the Far Right. Journal of Contemporary Ethnography, 36, 119-128.

Boonzaier, F., \& De La Rey, C. (2003). "He's a man, and I'm a woman": Cultural constructions of masculinity and femininity in South African women's narratives of violence. Violence Against Women, 9, 1003-1029.

Bouchard, P., Boily, I., \& Proulx, M-C. (2003). School success by gender: A catalyst for the masculinist discourse. Ottawa: Status of Women Canada.

Boyd, S. B. (2003). Walking the line: Canada's response to child custody law reform discourses. Family Law Quarterly, 21, 397-423.

Boyd, S. B., \& Young, C. F. L. (2002). Who influences family law reform? Discourses on motherhood and fatherhood in legislative reform debates in Canada. Studies in Law, Politics, and Society, 26, 43-75.

Breines, W., \& Gordon, L. (1983). The new scholarship on family violence. Signs, 8, 490-531.

Brown, D. (2001a, December 4). Men challenge "bible" of violence against women: A Toronto inquest will question the validity of a standard reference book. Ottawa Citizen. Retrieved February 12, 2007, from http://www.fact.on.ca/hadley/hadley_i.htm

Brown, D. (2001b, December 5). Burying the ghosts of a violent past: Husband in wheelchair became focus of wife's rage. Ottawa Citizen. Retrieved February 12, 2007, from http://www.fact.on.ca/hadley/ hadley_i.htm

Brown, D. (2001c, December 6). "I learned it's a system that doesn't listen": Wife still terrified by threat from family violence specialists. Ottawa Citizen. Retrieved February 12, 2007, from http://www.fact .on.ca/hadley/hadley_i.htm

Brown, D. (2001d, December 7). Turning domestic violence into a religion: Inquest an epic social debate. Ottawa Citizen. Retrieved February 12, 2007, from http://www.fact.on.ca/hadley/hadley_i.htm

Brown, D. (2001e, December 8). Cult of the domestic-violence industry: Where are the great numbers of victims we hear about? Ottawa Citizen. Retrieved February 12, 2007, from http://www.fact.on.ca/ hadley/hadley_i.htm

Brown, D. (2002, February 16). Recommendation 53: Electronic shackles. Ottawa Citizen. Retrieved February 12, 2007, from http://www.fact.on.ca/hadley/hadley_i.htm

Burgess-Proctor, A. (2006). Intersections of race, class, gender, and crime: Future directions for feminist criminology. Feminist Criminology, 1, 27-47.

Canadian Charter of Rights and Freedoms. (1982). Constitution Act, 1982, Enacted as Schedule B to the Canada Act 1982 (U.K.), c. 11.

Canadian Panel on Violence Against Women (1993). Changing the landscape: Ending the violenceachieving equality. Ottawa: Minister of Supply and Services Canada.

Carney, G. (2003). Communicating or just talking? Gender mainstreaming and the communication of global feminism. Women and Language, 26, 52-60.

Cherlin, A. J. (2004). The deinstitutionalization of American marriage. Journal of Marriage and Family, 66, 848-861.

Chesney-Lind, M. (2006). Patriarchy, crime, and justice: Feminist criminology in an era of backlash. Feminist Criminology, 1, 6-26.

Cook, S. L., \& Goodman, L. A. (2006). Beyond frequency and severity: Development and validation of the Brief Coercion and Conflict Scales. Violence Against Women, 12, 1050-1072.

Cooper, D. (1994). Productive, relational and everywhere? Conceptualising power and resistance within Foucauldian feminism. Sociology, 28, 435-454. 
Coyle, J. (2001, November 20). Group's ravings disturbing, dangerous. Toronto Star. Retrieved February 12, 2007, from http://www.fact.on.ca/hadley/hadley_i.htm

Crean, S. (1988). In the name of the fathers: The story behind child custody. Toronto: Amanita.

Dasgupta, S. D. (2002). A framework for understanding women's use of nonlethal violence in intimate heterosexual relationships. Violence Against Women, 8, 1364-1389.

Davenport, C., \& Ball, P. (2002). Views to a kill: Exploring the implications of source selection in the case of Guatemalan state terror, 1977-1995. The Journal of Conflict Resolution, 46, 427-450.

DeKeseredy, W. S. (1999). Tactics of the antifeminist backlash against Canadian national woman abuse surveys. Violence Against Women, 5, 1258-1276.

DeKeseredy, W. S. (2006). Future directions. Violence Against Women, 12, 1078-1085.

Department of Justice Canada. (2005). Policy statement and guidelines for public participation department of justice. Retrieved February 12, 2007, from http://www.justice.gc.ca/en/cons/pc_policy.html

Department of Justice Canada. (2006). Parenting after divorce: Child centered family justice strategy. Retrieved February 12, 2007, from http://www.justice.gc.ca/en/ps/pad/about/

Dilorio, J. A., \& Nusbaumer, M. R. (1993). Securing our sanity: Anger management among abortion escorts. Journal of Contemporary Ethnography, 21, 411-438.

Ditchburn, J. (2006a, October 6). Parties face off over funding for women's organizations. National Post, Online Edition.

Ditchburn, J. (2006b, August 25). Social Conservatives press Harper government to axe Status of Women Canada. Canadian Press, Online Edition.

Dobash, R. P., \& Dobash, R. E. (1995). Reflections on findings from the Violence Against Women Survey. Canadian Journal of Criminology, 37, 457-484.

Dobash, R. E., \& Dobash, R. P. (1998). Rethinking violence against women. Thousand Oaks, CA: Sage.

Dobash, R. P., \& Dobash, R. E. (2004). Women's violence to men in intimate relationships: Working on a puzzle. British Journal of Criminology, 3, 324-349.

Dobash, R. P., Dobash, R. E., Cavanagh, K., \& Lewis, R. (1998). Separate and intersecting realities. Violence Against Women, 4, 382-414.

Dobrowolsky, A., \& Jenson, J. (2004). Shifting representations of citizenship: Canadian politics of "women" and "children." Social Politics, 11, 154-180.

Domestic Violence Death Review Committee. (2003). Annual report of the Chief Coroner, Ontario: Case reviews of domestic violence deaths, 2002. Retrieved February 12, 2007, from http://www.mcscs.jus.gov .on.ca/english/publications/comm_safety/DVDRC_Report_2003.pdf

Earl, J., Martin, A., McCarthy, J. D., \& Soule, S. A. (2004). The use of newspaper data in the study of collective action. Annual Review of Sociology, 30, 65-80.

Einwohner, R. L. (2002). Bringing the outsiders in: Opponents' claims and the construction of animal rights activists' identity. Mobilization, 7, 253-268.

Eisenstein, H. (1996). Inside agitators: Australian femocrats and the state. Philadelphia: Temple University Press.

Equal Parents of Canada Web site. (n.d.). http://pages.interlog.com/ parental/epocnews/home.htm

Family of Men Web site. (n.d.). http://www.familyofmen.com

Fathers Are Capable Too Web site. (n.d.). http://www.fact.on.ca/

Fathers Canada 4 Justice Web site. (n.d.). http://www.fathers.ca

Fathers for Life Web site. (n.d.). http://www.fathersforlife.org

Federal-Provincial-Territorial Ministries Responsible for the Status of Women. (2002). Assessing violence against women: A statistical profile. Status of Women Canada. Available online at http://www.swc-cfc .gc.ca/pubs/0662331664/200212_0662331664_e.pdf

Fekete, J. (1994). Moral Panic: Biopolitics Rising. Montreal, PQ: R. Davies Publishing.

Ferree, M. M. (2003). Resonance and radicalism: Feminist framing in the abortion debates of the United States and Germany. American Journal of Sociology, 109, 304-344.

Fiebert, M. S. (2006). References examining assaults by women on their spouses or male partners: An annotated bibliography. Retrieved February 12, 2007, from http://www.csulb.edu/ mfiebert/assault.htm 
Gelles, R. J., \& Loseke, D. R. (1993). Current controversies on family violence. Newbury Park, CA: Sage. Government of Alberta. (2004a). Achieving a violence-free Alberta is everybody's business: Regional workshop guide and workbook. Retrieved June 20, 2006, from http://www.familyviolenceroundtable.gov .ab.ca/workbook.asp

Government of Alberta. (2004b). Alberta Roundtable on Family Violence and Bullying: Finding solutions together. Retrieved June 20, 2006, from http://www.familyviolenceroundtable.gov.ab.ca/pdf/ finding_solutions_together_report.pdf

Government of Alberta. (2004c). Framework for action: Moving community consultation to strategic action. Retrieved June 20, 2006, from http://www.familyviolenceroundtable.gov.ab.ca/pdf/ final_framework_for_action.pdf

Government of Alberta. (2004d). Roundtable on Family Violence and Bullying: Consultation summary report. Retrieved June 20, 2006, from http://www.familyviolenceroundtable.gov.ab.ca/pdf/final_ consultation_summary.pdf

Government of Ontario. (2005). A domestic violence action plan for Ontario. Ministry of Community and Social Services, Ontario. Retrieved February 12, 2007, from http://www.mcss.gov.on.ca/mcss/english/ news/backgrounders/050308.htm

Hamberger, L. K., \& Guse, C. E. (2002). Men's and women's use of intimate partner violence in clinical samples. Violence Against Women, 8, 1301-1331.

Hansard Association of Canada. (2007). What is Hansard? Retrieved May 27, 2007, from http://www .hansard.ca/what.html

Hunt, A. (1997). Moral regulation and making-up the new person: Putting Gramsci to work. Theoretical Criminology, 1, 275-301.

Hunt, A. (1999). Governing morals: A social history of moral regulation. Cambridge: Cambridge University Press.

Hunt, A., \& Wickham, G. (1994). Foucault and law: Towards a sociology of law as governance. London: Pluto Press.

Jaffe, P. G., \& Crooks, C. V. (2004). Partner violence and child custody cases: A cross-national comparison of legal reforms and issues. Violence Against Women, 10, 917-934.

Johnson, M. P. (1995). Patriarchal terrorism and common couple violence: Two forms of violence against women. Journal of Marriage and the Family, 57, 283-294.

Johnson, M. P. (2006). Conflict and control: Gender symmetry and asymmetry in domestic violence. Violence Against Women, 12, 1003-1018.

Juby, H., Le Bourdais, C., \& Marcil-Gratton, N. (2005). Sharing roles, sharing custody? Couples' characteristics and children's living arrangements at separation. Journal of Marriage and Family, 67, 157-172.

Kimmel, M. S. (2002). "Gender symmetry" in domestic violence: A substantive and methodological research review. Violence Against Women, 8, 1332-1363.

Koopmans, R., \& Olzak, S. (2004). Discursive opportunities and the evolution of right-wing violence in Germany. American Journal of Sociology, 110, 198-230.

Laing, M. (1999). For the sake of the children: Preventing reckless new laws. Canadian Journal of Family Law, 16, 229-282.

Landsberg, M. (2002, January 13). Pair try to explain away Hadley murder. Toronto Star. Retrieved February 12, 2007, from http://www.fact.on.ca/hadley/hadley_i.htm

Le Bourdais, C., \& Lapierre-Adamcyk, E. (2004). Changes in conjugal life in Canada: Is cohabitation progressively replacing marriage? Journal of Marriage and Family, 66, 929-942.

Legislative Assembly of Alberta. (2004). 25th Legislature, 4th Session. Meeting of the Legislative Assembly, February 24, 2004. Retrieved June 18, 2006, from http://www.assembly.ab.ca/ISYS/LADDAR_files/docs/hansards/han/legislature_25/session_4/20040224_1330_01_han.pdf

Legislative Assembly of Ontario. (2000a). 37th Parliament, 1st Session. Bill 117, an act to better protect victims of domestic violence (Chapter 33, Statutes of Ontario). Retrieved June 18, 2006, from http://www.ontla.on.ca/documents/Bills/37_Parliament/Session1/b117ra.pdf 
Legislative Assembly of Ontario. (2000b). 37th Parliament, 1st Session. Meetings of the Legislature, September 27, 2000; October 3, 4, 5, 2000; December 5, 12, 18, 2000. Retrieved June 18, 2006, from http://www.ontla.on.ca/hansard/37_parl/session1/CCommittees/justice/

Legislative Assembly of Ontario. (2000c). 37th Parliament, 1st Session. Standing Committee on Justice and Social Policy [Bill 117 Hearings] October 23, 24, 30, 31, 2000; November 14, 27, 2000. Retrieved June 18, 2006, from http://www.ontla.on.ca/hansard/37_parl/session1/ Committees/justice/

Lupri, E. (2004). Institutional resistance to acknowledging intimate male abuse (Revised). Paper presented at the Counter-Roundtable Conference on Domestic Violence, Calgary, Alberta, May 7. Retrieved February 12, 2007, from http://www.fact.on.ca/Info/dom/lupri05.htm

Lupri, E., \& Grandin, E. (2004). Intimate partner abuse against men. Ottawa: National Clearinghouse on Family Violence. Retrieved February 12, 2007, from http://www.phac-aspc.gc.ca/ncfv-cnivf/familyviolence/pdfs/Intimate_Partner.pdf

MacKinnon, C. A. (2006). Nationbuilding in Canada. In C. A. MacKinnon (Ed.), Are women human? And other international dialogues (pp. 77-85). Cambridge: The Belknap Press of Harvard University Press.

Mandell, D. (2002). "Deadbeat dads": Subjectivity and social construction. Toronto: University of Toronto Press.

Mann, R. M. (2000). Who owns domestic abuse? The local politics of a social problem. Toronto: University of Toronto Press.

Mann, R. M. (2002). Emotionality and social activism: A case study of a community

development effort to establish a shelter for women in Ontario. Journal of Contemporary Ethnography, 31, 251-284.

Mann, R. M. (2005). Fathers' rights, feminism and Canadian divorce law reform: 1998-2003. Studies in Law, Politics, and Society, 35, 29-63.

Mann, R. M. (2007). Intimate violence in Canada: Policy, politics and research on gender and perpetration/ victimization. In W. Antony \& L. Samuelson (Eds.), Power and resistance: Critical thinking about Canadian social problems (4th ed., pp. 50-74). Halifax, Nova Scotia, Canada: Fernwood.

Mautner, G. (2005). Time to get wired: Using Web-based Corpora in critical discourse analysis. Discourse \& Society, 16, 809-828.

McCaffrey, D., \& Keys, J. (2000). Competitive framing processes in the abortion debate: Polarizationvilification, frame saving, and frame debunking. The Sociological Quarterly, 41, 41-61.

McIlroy, A. (1998, December 5). Child custody: The great divide. Globe and Mail. Retrieved February 12, 2007, from http://www.fact.on.ca/newpaper/gm981205.htm

McMahon, M., \& Pence, E. (2003). Making social change: Reflections on individual and institutional advocacy with women arrested for domestic violence. Violence Against Women, 9, 47-74.

Men's Educational Support Association Web site. (n.d.). http://www.mesacanada.com/

Messner, M. A. (1998). The limits of "the male sex role": An analysis of the men's liberation and men's rights movements' discourse. Gender \& Society, 12, 255-276.

Miller, S. L. (2006). A specification of the types of intimate partner violence experienced by women in the general population. Violence Against Women, 12, 1105-1131.

Miller, S. L., \& Meloy, M. L. (2006). Women's use of force: Voices of women arrested for domestic violence. Violence Against Women, 12, 89-115.

Minaker, J. C., \& Snider, L. (2006). Husband abuse: Equality with a vengeance. Canadian Journal of Criminology and Criminal Justice, 48, 753-780.

Morrow, M., Hankivsky, O., \& Varcoe, C. (2004). Women and violence: The effects of dismantling the welfare state. Critical Social Policy, 24, 358-384.

National Council of Women of Canada Web site. (n.d.). http://www.ncwc.ca/

Ogrodnik, L. (2006). Family violence in Canada: A statistical profile 2006. Ottawa: Canadian Centre for Justice Statistics. Retrieved February 12, 2007, from http://www.phac-aspc.gc.ca/ncfv-cnivf/ familyviolence/pdfs/85-224-XIE2006000.pdf 
Ontario Association of Interval and Transition Houses Web site. (n.d.). http://www.oaith.ca/ Ontario Women's Directorate Web site. (n.d.). http://www.citizenship.gov.on.ca/owd/ Ontario Women's Justice Network Web site. (n.d.). http://www.owjn.org/

Polletta, F., \& Jasper, J. M. (2001). Collective identity and social movements. Annual Review of Sociology, 27, 283-305.

Potter, H. (2006). An argument for Black feminist criminology: Understanding African American women's experiences with intimate partner abuse using an integrated approach. Feminist Criminology, 1, 106-124.

Public Health Agency of Canada. (2004). Family Violence Initiative: Performance report 2002-2003 and 2003-2004. Ottawa: Government of Canada. Available online at http://www.phac-aspc.gc.ca/ncfvcnivf/familyviolence/pdfs/2004-Family-Violence-Initiative_E.pdf

Public Health Agency of Canada (2006). The Family Violence Initiative (FVI). Retrieved February 12, 2007, from http://www.phac-aspc.gc.ca/ncfv-cnivf/familyviolence/initiative_e.html

Research and Education for Solutions to Violence and Abuse Web site. (n.d.). http://www.umanitoba .ca/resolve/

Rhoades, H., \& Boyd, S. B. (2006). Reforming custody laws: A comparative study. International Journal of Law, Policy, and the Family, 18, 119-146.

Roberts, T. (2002). Serving Canadians: Review of provincial and territorial domestic violence legislation and implementation strategies. Retrieved June 20, 2006, from http://www.justice.gc.ca/en/ps/rs/rep/2001/ rr01-4a.html

Rohlinger, D. (2002). Framing the abortion debate: Organizational resources, media strategies and movement-countermovement dynamics. The Sociological Quarterly, 43, 479-507.

Rose, N. (1999). Powers of freedom: Reframing political thought. Cambridge: Cambridge University Press.

Rose, N., \& Valverde, M. (1998). Governed by law? Social \& Legal Studies, 7, 541-551.

Schwartz, M. D. (2005). The past and the future of violence against women. Journal of Interpersonal Violence, 20, 7-11.

Schweingruber, D., \& McPhail, C. (1999). A method for systematically observing and recording collective action. Sociological Methods \& Research, 27, 451-498.

Sexual Assault Centre of Edmonton Web site. (n.d.). http://www.sace.ab.ca/

Shaw, M., \& Andrew, C. (2005). Engendering crime prevention: International developments and the Canadian experience. Canadian Journal of Criminology and Criminal Justice, 47, 293-316.

Snider, L. (1998). Towards safer societies: Punishment, masculinities and violence against women. British Journal of Criminology, 38, 1-39.

Status of Women Canada Web site. (n.d.). http://www.swc-cfc.gc.ca/

Straus, M. A. (1993). Physical assault by wives: A major social problem. In R. J. Gelles \& D. R. Loseke (Eds.), Current controversies on family violence (pp. 67-87). Newbury Park, CA: Sage.

Straus, M. A. (2006). Future research on gender symmetry in physical assaults on partners. Violence Against Women, 12, 1086-1097.

Swan, S. C., \& Snow, D. L. (2006). The development of a theory of women's use of violence in intimate relationships. Violence Against Women, 12, 1026-1045.

Swidler, A. (1995). Cultural power and social movements. In H. Johnston \& B. Klandermans (Eds.), Social movements and culture (pp. 25-40). Minneapolis: University of Minnesota Press.

Tarrow, S. (1996). Social movements in contentious politics: A review article. American Political Science Review, 90, 874-883.

Tarrow, S. (1998). Power in movement: Social movements and contentious politics (2nd ed.). Cambridge: Cambridge University Press.

Taylor, V., \& Rupp, L. J. (2002). Loving internationalism: The emotion culture of transnational women's organizations, 1888-1945. Mobilization, 7, 141-158.

Taylor, V., \& Whittier, N. (1995). Analytical approaches to social movement culture: The culture of the women's movement. In H. Johnston \& B. Klandermans (Eds.), Social movements and culture (pp. 163-187). Minneapolis: University of Minnesota Press. 
Towns, A., \& Adams, P. (2000). "If I really loved him enough, he would be okay": Women's accounts of male partner violence. Violence Against Women, 16, 558-585.

Tutty, L. (1999). Husband abuse: An overview of research and perspectives. Ottawa: Health Canada. Retrieved February 12, 2007, from http://www.phac-aspc.gc.ca/ncfv-cnivf/familyviolence/pdfs/ husbandenglish.pdf

Walker, G. A. (1990). Family violence and the women's movement. (1st ed.) Toronto: University of Toronto Press.

Weedon, C. (1987). Feminist practice \& poststructuralist theory. (1st ed.) New York: Basil Blackwell.

Weldon, S. L. (2002). Protest, policy, and the problem of violence against women: A cross-national comparison. Pittsburgh, Pennsylvania: University of Pittsburgh Press.

Whittier, N. (2001). Emotional strategies: The collective reconstruction and display of oppositional emotions in the movement against child sexual abuse. In J. Goodwin \& J. M. Jasper (Eds.), Passionate politics: Emotions and social movements (pp. 233-250). Chicago: University of Chicago Press.

Wodak, R. (2006). Mediation between discourse and society: Assessing cognitive approaches in CDA. Discourse Studies, 8, 179-190.

Worcester, N. (2002). Women's use of force: Complexities and challenges of taking the issue seriously. Violence Against Women, 8, 1390-1415.

Ruth M. Mann teaches in the Criminology Program of the Department of Sociology and Anthropology at the University of Windsor (Windsor, ON, Canada). Dr. Mann is principle investigator on two research projects, each focusing on the governance of a politically contentious social problem. The first is on men's rights/fathers' rights activism and its impacts on feminist-influenced policies relevant to women's equality, autonomy, and safety (funded by the Health Research Centre for the Study of Violence Against Women, University of Windsor). The second, with coinvestigator Dr. Charlene Senn (Department of Psychology), is on youth violence intervention across school, social service, and youth justice domains under Canada's "new" (2003) Youth Criminal Justice Act (funded by the Social Sciences and Humanities Research Council of Canada). 